\title{
Pharmacokinetic-pharmacodynamic correlation of imipenem in pediatric burn patients using a bioanalytical liquid chromatographic method
}

\author{
Silvia Regina Cavani Jorge Santos ${ }^{1, *}$, Cristina Sanches-Giraud ${ }^{2}$, Carlindo Vieira Silva Júnior ${ }^{1}$, \\ David Souza Gomez ${ }^{3}$
}

\author{
${ }^{1}$ School of Pharmaceutical Sciences, University of São Paulo, São Paulo, SP, Brazil, ${ }^{2}$ Federal University of São João del Rei, \\ Divinópolis, MG, Brazil, ${ }^{3}$ School of Medicine, University of São Paulo, São Paulo, SP, Brazil
}

\begin{abstract}
A bioanalytical method was developed and applied to quantify the free imipenem concentrations for pharmacokinetics and PK/PD correlation studies of the dose adjustments required to maintain antimicrobial effectiveness in pediatric burn patients. A reverse-phase Supelcosil LC18 column ( 250 x $4.6 \mathrm{~mm} 5 \mathrm{micra})$, binary mobile phase consisting of $0.01 \mathrm{M}$, pH 7.0 phosphate buffer and acetonitrile (99:1, v/v), flow rate of $0.8 \mathrm{~mL} / \mathrm{min}$, was applied. The method showed good absolute recovery (above $90 \%$ ), good linearity (0.25-100.0 $\left.\mu \mathrm{g} / \mathrm{mL}, \mathrm{r}^{2}=0.999\right)$, good sensitivity (LLOQ: $0.25 \mu \mathrm{g} / \mathrm{mL}$; LLOD: $0.12 \mu \mathrm{g} / \mathrm{mL}$ ) and acceptable stability. Inter/intraday precision values were $7.3 / 5.9 \%$, and mean accuracy was $92.9 \%$. A bioanalytical method was applied to quantify free drug concentrations in children with burns. Six pediatric burn patients (median 7.0 years old, $27.5 \mathrm{~kg}$ ), normal renal function, and 33\% total burn surface area were prospectively investigated; inhalation injuries were present in 4/6 (67\%) of the patients. Plasma monitoring and PK assessments were performed using a serial blood sample collection for each set, totaling 10 sets. The $\mathrm{PK} / \mathrm{PD}$ target attained $(40 \% \mathrm{~T}>\mathrm{MIC})$ for each minimum inhibitory concentration (MIC: $0.5,1.0,2.0,4.0 \mathrm{mg} / \mathrm{L}$ ) occurred at a percentage higher than $80 \%$ of the sets investigated and $100 \%$ after dose adjustment. In conclusion, the purification of plasma samples using an ultrafiltration technique followed by quantification of imipenem plasma measurements using the LC method is quite simple, useful, and requires small volumes for blood sampling. In addition, a small amount of plasma $(0.25 \mathrm{~mL})$ is needed to guarantee drug effectiveness in pediatric burn patients. There is also a low risk of neurotoxicity, which is important because pharmacokinetics are unpredictable in these critical patients with severe hospital infection. Finally, the PK/PD target was attained for imipenem in the control of sepsis in pediatric patients with burns.
\end{abstract}

Uniterms: Imipenem/quantification. Antibiotics/dosage. Pediatric patients/burn/antibiotics use. High Performance Liquid Chromatography/quantitative analysis. Drug plasma monitoring. PK/PD.

Desenvolveu-se e aplicou-se método bioanalítico para quantificar concentrações de imipenem livre para estudos de farmacocinética (PK) e de correlação PK/PD dos ajustes de dose requeridos para manter a efetividade antimicrobiana em pacientes pediátricos queimados. Utilizou-se coluna Supelcosil LC18 ( 250 x 4,6 mm 5 micra), fase móvel binária, consistindo de tampão fosfato $0,01 \mathrm{M} \mathrm{pH} \mathrm{7,0} \mathrm{e} \mathrm{acetonitrila}$ ( $99: 1, \mathrm{v} / \mathrm{v})$ e fluxo de $0,8 \mathrm{~mL} / \mathrm{min}$. O método mostrou boa recuperação absoluta (acima de $90 \%$ ), boa linearidade (0,25-100,0 $\left.\mu \mathrm{g} / \mathrm{mL}, \mathrm{r}^{2}=0.999\right)$, boa sensibilidade (LLOQ: 0,25 $\mu \mathrm{g} / \mathrm{mL}$; LLOD: 0,12 $\mu \mathrm{g} / \mathrm{mL}$ ) e estabilidade aceitável. Os valores de precisão inter/intradia foram 7,3/5,9\% e a exatidão média foi de $92,9 \%$. O método bioanalítico foi aplicado para quantificar concentrações de fármaco livre em crianças com queimaduras, Seis pacientes pediátricos queimados (idade média de 7,0 anos, 27,5 kg), com função renal normal e $33 \%$ da superfície total queimada foram investigados prospectivamente. Lesões por inalação estavam presentes em 4/6 (67\%) dos pacientes. O monitoramento plasmático e a as avaliações de PK foram efetuadas utilizando coleção de amostras seriais de sangue para cada série,

*Correspondence: S. R. C. J. Santos. Departamento de Fármácia. Faculdade de Ciências Farmacêuticas. Universidade de São Paulo. Av. Prof. Lineu Prestes, n.580, 05508-000 - São Paulo - SP, Brasil. E-mail: pharther@usp.br 
totalizando 10 conjuntos. O alvo $\mathrm{PK} / \mathrm{PD}$ alcançado (40\% $\mathrm{T}>\mathrm{MIC})$ para cada concentração inibitória mínima (MIC: 0,5, 1,0, 2,0, 4,0 mg/L) ocorreu em porcentagem maior do que $80 \%$ dos conjuntos investigados e $100 \%$ após o ajuste de dose. Em conclusão, a purificação das amostras do plasma usando técnica de ultrafiltração seguida de quantificação das medidas do imipenem no plasma usando método de cromatografia líquida é bastante simples, útil e necessita de pequenos volumes para as amostras de sangue. Além disso, pequena quantidade de plasma $(0,25 \mathrm{~mL})$ é necessário para garantir a efetividade do fármaco nos pacientes pediátricos queimados. Há, ainda, baixo risco de neurotoxicidade, o que é importante, visto que as farmacocinéticas são imprevisíveis nesses pacientes críticos, com grave infecção hospitalar. Finalmente, o alvo PK/PD foi alcançado para o imipenem no controle da sepse em pacientes pediátricos com queimaduras.

Unitermos: Imipenem/quantificação. Antibióticos/dosagem. Pacientes pediátricos/queimaduras/uso de antibióticos. Cromatografia líquida de alta eficiência/análise quantitativa. Monitoramento plasmático. $\mathrm{PK} / \mathrm{PD}$.

\section{INTRODUCTION}

Imipenem is a broad-spectrum carbapenem agent that has been widely used to treat life-threatening infections in critically ill and burn patients (Belzeberg et al., 2004). Imipenem has been shown to have doseindependent kinetics in male adult patients with preserved renal function, and its biological half-life of approximately one hour is a function of fast excretion of the drug by the kidneys (Drusano et al., 1984; Belzeberg et al., 2004; Zhanel et al., 2007).

In a burn injury, several factors may affect a drug's PK, such as the extension of area affected, depth of the burn, the presence of sepsis, the degree of hydration, serum protein concentrations, age, creatinine clearance $\left(C L_{\mathrm{cr}}\right)$ and the time since the injury (Weinbren, 1999; Blanchet et al, 2008). Patients with major burns have shown a reduction of antimicrobial activity resulting from PK alterations due to the extensive hydration and physiological changes following the burn injury (Fry, 1996). However, few clinical studies have examined imipenem prescribed to pediatric patients with burns to control infection with Gram negative pathogens and have provided data related to PK. A thorough understanding of imipenem pharmacokinetics in pediatric patients is important for optimizing imipenem dosing regimens to guarantee drug effectiveness in controlling infection against nosocomial pathogens (Belzeberg et al., 2004).

A survey of the literature has revealed several analytical methods to determine imipenem in biological fluids using high-cost procedures, including LC-MS/ MS (Xu et al., 2009) and capillary zone electrophoresis (Taniguchi et al., 1999) or methods that rely on low-cost and very simple microbiological assays with quite low specificities (Pietroski et al., 1991).

Then, the aim of the present study was to develop and to validate a simple bioanalytical liquid chromatographic method to determine imipenem in plasma according to FDA guidelines (FDA, 2001) for pharmacokinetics and PK/PD correlation studies that focus on the dose adjustments required to ensure antimicrobial effectiveness in pediatric burn patients.

\section{MATERIAL AND METHODS}

\section{Reagents and chemicals}

Drug standards of imipenem and ceftriaxone (internal standard) and 3-( $N$-morpholino)-propane sulphonic acid (MOPS) were purchased from Sigma (St. Louis, MO, USA). All solvents (LC grade) and reagents for drug plasma purification and LC analysis were purchased from Merck (Darmstadt, Germany). Purified water was obtained from Millipore Simplicity System (Milford, MA, USA).

\section{LC system}

The chromatographic system consisted of a Shimadzu model LC-10AVP solvent delivery module (Kyoto, Japan) equipped with a SCL-10AVP controller/ software Class VP, autosampler model SIL-10ADVP and a detector UV-VIS model SPD-10ADPV. The peak area ratio of imipenem to its internal standard was integrated using Class VP/computer Intel Celeron software. The analytical column was a Supelcosil LC18, 250 x $4.6 \mathrm{~mm}$, $5 \mu \mathrm{m}$ (Supelco, Bellefonte, PA, USA) connected to a Nova Pak C18 guard column (Waters Assoc., Milford, USA).

The binary mobile phase was freshly prepared on the day of its use from a mixture of $0.01 \mathrm{M}$ phosphate buffer $\mathrm{pH} 7.0$ that had been previously filtered through a 0.45 $\mu \mathrm{m}$ filter and acetonitrile $(99: 01, v / v)$, which was helium degassed for one minute. The chromatographic analysis was performed using an isocratic system at a flow rate of 
$0.8 \mathrm{~mL} / \mathrm{min}$ at room temperature. The injection volume was $5 \mu \mathrm{L}$, and the effluent was monitored at $300 \mathrm{~nm}$. A run time of 15 minutes was required to guarantee the selectivity of chromatographic analysis.

\section{Preparations of standards and internal controls}

The standard stock solution was prepared by dissolving the appropriate amount of imipenem standard $(10 \mathrm{mg})$, which was accurately weighted in the $5 \mathrm{~mL}$ volumetric flask with purified water, to reach a final drug concentration of $1.0 \mathrm{mg} / \mathrm{mL}$. The standards were prepared to obtain 100.0, 50.0, 20.0, 10.0, 5.0, 2.0, 1.0, 0.5, $0.25 \mu \mathrm{g} / \mathrm{mL}$ of imipenem by adding the appropriate amount of stock drug standard solution to a stock solution of drug-free fetal bovine serum (blank serum) and $0.5 \mathrm{~mL}$ of a mixture containing $0.5 \mathrm{M}$ MOPS-ethylene glycol aqueous solution. Linearity was investigated in the range of $0.25-100.0 \mu \mathrm{g} / \mathrm{mL}$, and the calibration curve was constructed daily. Additionally, internal controls were prepared by diluting the stock solution with a drug-free fetal bovine blank serum to obtain the high $(80 \mu \mathrm{g} / \mathrm{mL})$, medium high $(40 \mu \mathrm{g} / \mathrm{mL})$, medium low $(4.0 \mu \mathrm{g} / \mathrm{mL})$ and low $(1.0 \mu \mathrm{g} / \mathrm{mL})$ concentrations and stored until assay in a deep freezer at $-80{ }^{\circ} \mathrm{C}$.

The internal standard (IS) was ceftriaxone, and the stock solution was prepared in purified water to obtain $1 \mathrm{mg} / \mathrm{mL}$ and kept at $-80^{\circ} \mathrm{C}$ until assay. The working solution of the internal standard was freshly prepared by diluting the stock solution with water to reach the $100 \mu \mathrm{g} / \mathrm{mL}$ drug concentration.

\section{Sample ultrafiltration plasma purification procedure}

Drug plasma measurements were performed by high performance liquid chromatography, requiring the addition $0.25 \mathrm{~mL}$ plasma to a mixture containing $0.5 \mathrm{M}$ MOPS-ethylene glycol aqueous solution $(1: 1, \mathrm{v} / \mathrm{v})$ and the internal standard (10 $\mu \mathrm{g}$ /assay), followed by a protein removal procedure prior to HPLC analysis. Purification of the plasma samples required a Amicon Ultra - $0.5 \mathrm{~mL}$ Ultracel 30k centrifugal filter device (Merck-Millipore Corporation, USA) to provide fast ultrafiltration during spinning at $8,000 \mathrm{~g}, 4^{\circ} \mathrm{C}$ on a centrifuge with a fixed-angle rotor for 10 minutes. A filter device with the capacity for high concentration factors and easy concentrate recovery from dilute and complex sample matrices with $30 \mathrm{~K}$ cutoffs (30,000 NMWL: nominal molecule weight limit) was applied. After centrifugation, a $0.20 \mathrm{~mL}$ volume of the fluid protein removed from the filtrate collection tube was transferred to a $1 \mathrm{~mL}$ vial containing a microvial/vial insert for drug analysis in the autosampler.

\section{Linearity, calibration curve and calculation procedures}

The calibration curve was obtained by plotting the peak area ratio obtained for imipenem to its internal standard as a function of drug plasma concentration and nominal values. The linear regression curve was obtained using the following equation: $y=a+b x$, where $(x)$ is the drug concentration, (y) the peak area ratio (a) the intercept and (b) the slope. The calibration curve was accepted for the linear coefficient of determining the estimated $\left(\mathrm{r}^{2}>0.99\right)$ and systematic error $(S E \%)$ lower than $15 \%$ for all standards with the exception of the lower limit of quantifications (LOQ: $S E \leq 20 \%$ ). The parameter can be estimated by the value of the mean back-calculated concentrations divided by theoretical concentrations, expressed as a percentage. Additionally, at least six calibrators were considered to construct the daily calibration curve $0.25-100.0 \mu \mathrm{g} / \mathrm{mL}$, and the daily curve was accepted if at least $6 / 8$ of the internal controls (high, medium and low concentrations analyzed in duplicate) presented with a systematic error lower than $15 \%$. At least one control of each concentration was required to be within the acceptable variation. Once accepted, the calibration curve was applied to estimate drug plasma concentration in plasma samples collected from the patient. The linearity of the bioanalytical method was determined in triplicate for each concentration ranging from 0.25 to $100.0 \mu \mathrm{g} / \mathrm{mL}$.

\section{Accuracy, precision and recovery}

The precision of the bioanalytical method was expressed by relative standard deviation as a percentage (RSD). The intra-day precision was evaluated by analyzing the three replicates for the high $(80 \mu \mathrm{g} / \mathrm{mL})$, medium high $(40 \mu \mathrm{g} / \mathrm{mL})$, medium low $(4.0 \mu \mathrm{g} / \mathrm{mL})$ and low $(1.0 \mu \mathrm{g} / \mathrm{mL})$ concentrations. The inter-day precision was determined by analyzing the three replicates for the high, medium and low concentrations of imipenem on three different days $(n=27)$.

Accuracy was evaluated in three different concentrations by analyzing the triplicates and was expressed as the percentage of inaccuracy. The intraday accuracy was evaluated by analyzing the three replicates of the high, medium high, medium low and low concentrations. The inter-day accuracy was determined by analyzing the three replicates of the high, medium and low concentrations of imipenem on three different days $(n=27)$. 
The absolute recovery values for imipenem and the internal standard from plasma, expressed as percentage, were estimated by the peak area integrated for each drug (10 replicates each) in plasma, assayed according to the described procedure, versus the peak area integrated for each drug after direct injection when considering the same nominal drug concentration. The efficiency of the relative recovery was estimated by the peak area ratio integrated for the analyte and its internal standard (10 replicates), assayed according to the described procedure, versus the peak area ratio integrated for the drug and its internal standard after direct injection.

\section{Specificity}

The specificity of the bioanalytical method and the ability to accurately measure an analyte in the presence of endogenous compounds were evaluated by analyzing samples in drug-free plasma (normal, hemolyzed and lipemic plasma samples) by applying the previously introduced procedure; the retention times of endogenous compounds were compared with those obtained for imipenem and the internal standard in normal plasma extract.

\section{Limit of detection and limit of quantification}

The lower limits of detection (LLOD) and of quantification (LLOQ) were determined based on the analysis of ten replicates for each parameter considered. The LLOQ was defined as the lowest drug plasma concentration of the calibration daily curve that could be determined with an accuracy of $80-120 \%$ and precision lower than $20 \%$.

\section{Stability study}

Spiked blank plasma was analyzed by LC after three freezing/thawing cycles considering three different concentrations $(1.0,40,80 \mu \mathrm{g} / \mathrm{mL})$ analyzed in triplicate by applying the analytical procedure as detailed above. Data were represented by the systematic error, expressed as a percentage. The acceptance criterion for all concentrations studied and adopted was lower than the $15 \%$ variation expressed by the systematic error.

\section{Therapeutic drug monitoring and pharmacokinetics of imipenem in burned children}

The clinical protocol was a prospective, open-label study approved by the Ethical Committee (Protocol $\mathrm{n}^{\circ}$ 0069/09) of Hospital das Clínicas, Medical School, University of Sao Paulo. The study was conducted from April 2009 to March 2013, and informed written consent was obtained from all legally designated patient representatives.

Pediatric patients up to 10 years old from the Burn Intensive Care Unit (ICU), presenting with severe thermal injuries and a sepsis diagnosis (clinical and laboratorial) (Greenhalgh et al., 2007) were eligible for inclusion. Patients with imipenem intolerance or significant renal impairment were excluded. The study was based on imipenem treatment for suspected or documented gramnegative nosocomial infections. Initially, the patients were treated four times a day with systemic imipenem (2 g daily) through a 30-minute infusion every 6 hours according to the institutional protocol.

Complete medical histories, physical examinations, microbiological profile and laboratory data were obtained for each enrolled patient. Creatinine clearance was estimated by Schwartz's method (Schwartz et al., 1976). Individual demographic and clinical characteristics are shown in Table I.

Patient blood samples were obtained by a venous catheter after achieving steady state, with a time point periodicity equal to at least five elimination half-lives. After drug infusion, serial blood samples $(1 \mathrm{~mL})$ were collected into sodium EDTA tubes for drug plasma assay at 1, 2, 3, 4 and 6 hours. During the patients' stay in the ICU, imipenem pharmacokinetics were investigated weekly or when a re-infection by imipenem-sensitive strains occurred.

Imipenem plasma concentration-time data were analyzed using PK Solutions 2.0 software (Summit, USA), and the area under the curve at the time/dose interval $\left(\mathrm{AUC}_{\tau}^{\mathrm{ss}}\right)$, the elimination rate constant $(\mathrm{Kel})$, the biological half-life $\left(\mathrm{t}_{(1 / 2) \beta}\right)$, the plasma clearance $\left(\mathrm{CL}_{\mathrm{T}}\right)$ and the volume of distribution $\left(\mathrm{Vd}^{\mathrm{ss}}\right)$ were estimated. Antimicrobial susceptibility expressed by the minimum inhibitory concentration (MIC) was obtained from the confirmed data after strain documentation by the Microbiological laboratory/Central Laboratory by VITEK micro diffusion technique plus an automated method according to Clinical Laboratory Standards Institute (CLSI M100). When any strain was documented by the hospital Central Laboratory in time, PK/PD was estimated based on MIC data obtained from the European Committee on Antimicrobial Susceptibility Testing (EUCAST, 2013). $\mathrm{PK} / \mathrm{PD}$ data were based on the $40 \% f \mathrm{~T}>\mathrm{MIC}$ for each patient investigated; then, the targets for the control of infection and drug effectiveness against strains with MIC values of $0.5,1.0,2.0$ and $4.0 \mathrm{mg} / \mathrm{L}$ were based on drug 
TABLE I - Demographic and clinical characteristics of paediatric burn patients after thermal injury: individual and population data $(\mathrm{n}=6)$

\begin{tabular}{|c|c|c|c|c|c|c|c|c|c|c|}
\hline $\begin{array}{l}\text { Patient } \\
\text { allocation }\end{array}$ & Gender & $\begin{array}{l}\text { Age } \\
(\mathrm{yrs})\end{array}$ & Weight (kg) & $\begin{array}{c}\text { BMI } \\
(\mathrm{kg} / \mathrm{m} 2)\end{array}$ & $\begin{array}{c}\text { TBSA } \\
(\%)\end{array}$ & $\begin{array}{c}\text { CLcr }(\mathrm{mL} / \\
\mathrm{min})\end{array}$ & $\begin{array}{c}\text { Inhalation } \\
\text { injury }\end{array}$ & $\begin{array}{c}\text { Endotracheal } \\
\text { intubation }\end{array}$ & $\begin{array}{c}\text { Vasoactive } \\
\text { Drugs }\end{array}$ & Outcome \\
\hline$\# 1$ & M & 09 & 30 & 17.1 & 30 & 207.4 & $(-)$ & $(-)$ & $(-)$ & Survivor \\
\hline$\# 3$ & M & 02 & 12 & 14.8 & 15 & 682.0 & $(+)$ & $(+)$ & $(-)$ & Survivor \\
\hline$\# 4$ & M & 01 & 16 & 25.0 & 28 & 702.2 & $(-)$ & $(-)$ & $(-)$ & Survivor \\
\hline Patients & $5 \mathrm{M} / 1 \mathrm{~F}$ & NAP & NAP & NAP & NAP & NAP & $4 / 6$ & $4 / 6$ & $3 / 6$ & $5 / 6$ \\
\hline Median & NAP & 7.0 & 27.5 & 21.5 & 33.0 & 377.8 & NAP & NAP & NAP & NAP \\
\hline $\begin{array}{l}\text { Quartile } \\
25-75 \%\end{array}$ & NAP & $2.3-8.0$ & $16.0-37.5$ & $17.3-23.7$ & $28.9-45.0$ & $246.9-608.5$ & NAP & NAP & NAP & NAP \\
\hline
\end{tabular}

Abbreviations - M: male; F: female; (+) presence; (-) absence; BMI: body mass index; TBSA: total burn surface area; CLcr: creatinine clearance; Quartile (25-75\%); NAP: not applicable.

plasma concentrations for more than $40 \%$ of the dosing interval (Ikawa et al., 2008).

\section{Data analysis}

Statistical data analysis was carried out using GraphPad Prism Version 4.0 (GraphPad Software Corporation, San Diego, USA). P-values below 0.05 were considered to be significant. Quantitative variables were described using central tendency and dispersion measures.

\section{RESULTS AND DISCUSSION}

\section{Experimental}

Several drug measurements have been reported previously for imipenem in biological matrices by applying microbiological techniques (Pietroski et al., 1991) and chromatographic methods such as LC-UV (Buckley et al., 1992; Belzeberg et al., 2004; Ebey, Boucher, Pieper, 1988; Garcia-Capdevila et al., 1997; Gravallese et al., 1984; Kurihara, Kizu, Hori, 2008; Legrand et al., 2008;) and LC-MS/MS (Xu et al., 2009). With regard to the drug assay for imipenem dose adjustment, LC-UV was preferred by its relative low cost relative to routine $\mathrm{LC} / \mathrm{MS} / \mathrm{MS}$ drug plasma measurements.

Peaks monitored at $300 \mathrm{~nm}$ were eluted at $5.5 \mathrm{~min}$ and $11.7 \mathrm{~min}$, respectively for IS and imipenem. The total time required for each chromatographic run was 10 minutes to guarantee the high selectivity and specificity; chromatograms are presented in Figure 1 . The specificity of the bioanalytical method was guaranteed once the endogenous compounds were eluted, up to 4.5 minutes of chromatographic run time; consequently, no peaks were co-eluted with the analyte or its internal standard in the analytical run.

When considering plasma purification, ultrafiltration is a more suitable assay technique than the precipitation of plasma proteins for free-drug plasma monitoring in clinical laboratories (Buckley et al., 1992; Dailly et al., 2011; Ebey, Boucher, Pieper, 1988; Garcia-Capdevila et al., 1997; Gravallese et al., 1984; Verdier et al., 2011) or liquid-liquid extraction (Dailly et al., 2003).

Validated method parameters for the quantification of imipenem in plasma according to FDA guidance (FDA, 2001) are shown in Table II.

For the bioanalytical method, linearity was determined in the range of $0.25-100.0 \mu \mathrm{g} / \mathrm{mL}$, and data were expressed by the intercept and the slope of the linear function as the mean, standard error of the mean (SEM) and linear coefficient of determination $\left(r^{2}\right)$ as follows: intercept 0.0146 (SEM: 0.0183), slope 0.0273 (SEM: 0.0004) and $\mathrm{r} 2: 0.998$. Based on plasma analysis $(250 \mu \mathrm{L})$ in 10 replicates, the lower limit of detection was $0.12 \mu \mathrm{g} / \mathrm{mL}$, and the lower limit of quantification was $0.25 \mu \mathrm{g} / \mathrm{mL}$.

The linearity of the LC-UV measurements data obtained in the present study ( 0.25 up to $100.0 \mu \mathrm{g} / \mathrm{mL})$ is superior or comparable to those previously reported (Buckley et al., 1992; Belzeberg et al., 2004; Dailly et al., 2011; Ebey, Boucher, Pieper, 1988; Garcia-Capdevila et al., 1997; Gravallese et al., 1984; Verdier et al., 2011). Additionally, the selectivity and specificity for imipenem measurements in plasma extracts were guaranteed by the detection of the analyte at $300 \mathrm{~nm}$, as previously 

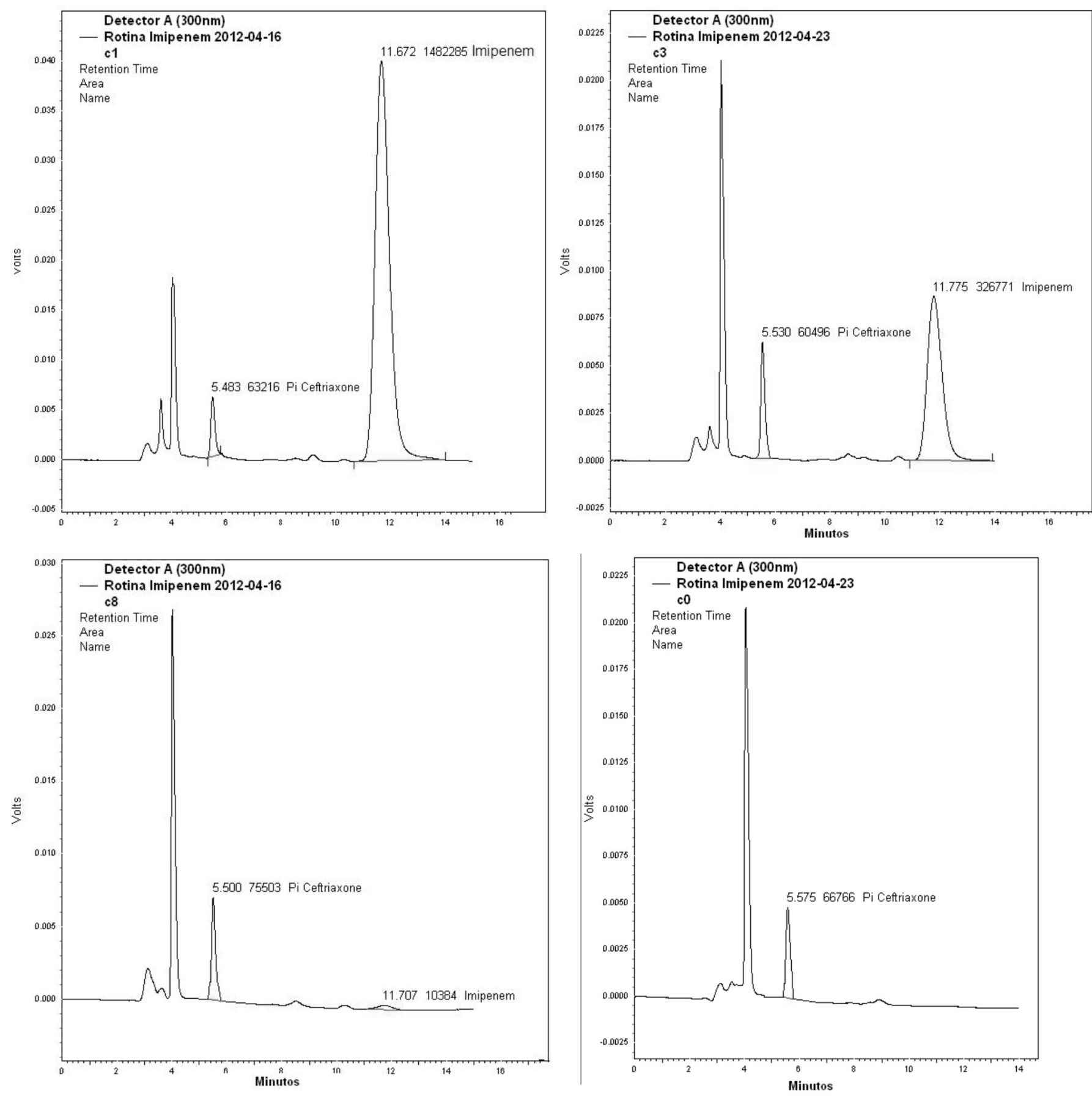

FIGURE 1 - Chromatographic profile of imipenem in plasma purified extract, run time 15 min (A): High drug concentration $(100.0 \mu \mathrm{g} / \mathrm{mL})$ plus ceftriaxone (IS); (B) Medium drug concentration $(20.0 \mu \mathrm{g} / \mathrm{mL})$ plus IS; (C) Low drug concentration $(4.0 \mu \mathrm{g} / \mathrm{mL})$ plus IS; (D): Blank plasma plus IS; retention times obtained were $5.7 \mathrm{~min}$ for for ceftriaxone (IS) and $11.7 \mathrm{~min}$ for imipenem.

recommended (Buckley et al., 1992; Dailly et al., 2011; Garcia-Capdevila et al., 1997; Verdier et al., 2011).

The bioanalytical method of therapeutic drug plasma monitoring, pharmacokinetic study and dose adjustments by PK/PD modelling in pediatric patients showed good sensitivity, absolute and relative recoveries, linearity and stability, with acceptable accuracy and precision (Table II).
Thus, good sensitivity for plasma imipenem measurements was obtained in the study as a consequence of high drug recovery, an essential factor for drug analyses in small plasma volumes that clearly contributes to reducing volume in blood sampling.

Additionally, good drug plasma stability was demonstrated after three consecutive thawing/freezing 
TABLE II - Confidence limits of bioanalytical method for imipenem plasma measurements

\begin{tabular}{|c|c|c|}
\hline Parameter & Unit & Confidence Limits \\
\hline Linearity $(n=3)$ & $\mu \mathrm{g} / \mathrm{mL}$ & $0.25-100.0$ \\
\hline Linear regression ( $\mathrm{n}=3$ curves) & & $r^{2}: 0.9974$ \\
\hline LLOD: $0.12 \mu \mathrm{g} / \mathrm{mL}(\mathrm{n}=10)$ & $R S D$ & 18.95 \\
\hline LLOQ: $0.25 \mu \mathrm{g} / \mathrm{mL}(\mathrm{n}=10)$ & $R S D$ & 14.86 \\
\hline \multicolumn{3}{|l|}{ Recovery } \\
\hline Absolute $(\mathrm{n}=10)$ analite/IS & $\%$ & $93.0 / 64.2$ \\
\hline Relative $(\mathrm{n}=10)$ analite & $\%$ & 144.9 \\
\hline Precision/within-day $(\mathrm{n}=9$ ) & $R S D$ (mean: 2.0 ) & \\
\hline $80 \mu \mathrm{g} / \mathrm{mL}$ & & 5.3 \\
\hline $40 \mu \mathrm{g} / \mathrm{mL}$ & & 6.7 \\
\hline $1.0 \mu \mathrm{g} / \mathrm{mL}$ & & 5.8 \\
\hline Precision/between-day $(\mathrm{n}=27$ ) & $R S D$ (mean: 2.3 ) & \\
\hline $80 \mu \mathrm{g} / \mathrm{mL}$ & & 6.5 \\
\hline $40 \mu \mathrm{g} / \mathrm{mL}$ & & 7.2 \\
\hline $1.0 \mu \mathrm{g} / \mathrm{mL}$ & & 8.3 \\
\hline Accuracy/within-day $(\mathrm{n}=9)$ & $\%$ (bias: $1.49 \%$ ) & \\
\hline $80 \mu \mathrm{g} / \mathrm{mL}$ & & 93.4 \\
\hline $40 \mu \mathrm{g} / \mathrm{mL}$ & & 90.1 \\
\hline $1.0 \mu \mathrm{g} / \mathrm{mL}$ & & 91.3 \\
\hline Accuracy/between-day $(\mathrm{n}=27)$ & $\%$ (bias: $1.65 \%$ ) & \\
\hline $80 \mu \mathrm{g} / \mathrm{mL}$ & & 95.2 \\
\hline $40 \mu \mathrm{g} / \mathrm{mL}$ & & 94.7 \\
\hline $1.0 \mu \mathrm{g} / \mathrm{mL}$ & & 91.7 \\
\hline Stability /thawing cycles & $S E \%$ & \\
\hline Cycle $1(\mathrm{n}=12)$ & & 6.6 \\
\hline Cycle $2(n=12)$ & & 4.4 \\
\hline Cycle $3(n=12)$ & & 3.5 \\
\hline Stability/ short term & $S E \%$ & \\
\hline $40 \mu \mathrm{g} / \mathrm{mL}(\mathrm{n}=3)$ & & 8.2 \\
\hline $20 \mu \mathrm{g} / \mathrm{mL}(\mathrm{n}=3)$ & & 7.9 \\
\hline $0.6 \mu \mathrm{g} / \mathrm{mL}(\mathrm{n}=3)$ & & 9.0 \\
\hline Stability/ post-preparative & $S E \%$ & \\
\hline $40 \mu \mathrm{g} / \mathrm{mL}(\mathrm{n}=3)$ & & 7.2 \\
\hline $20 \mu \mathrm{g} / \mathrm{mL}(\mathrm{n}=3)$ & & 7.3 \\
\hline $0.6 \mu \mathrm{g} / \mathrm{mL}(\mathrm{n}=3)$ & & 6.9 \\
\hline
\end{tabular}

Abbreviations: Relative Standard Deviation (RSD), standard deviation of mean $(S D)$, systematic error $(S E \%)$, Internal standard (IS), LLOD: lower limit of detection; LLOQ: lower limit of quantification.

cycles on the bench; in addition, the post processing stability was guaranteed at room temperature up to 24 hours for purified extracts on the rack of auto sampler (Table II).

In general, blood sampling for laboratory measurements is mainly a limiting factor for drug plasma monitoring in children; consequently, lower volumes for drug plasma measurements in pediatric patients would be an additional advantage. 
TABLE III - Imipenem pharmacokinetics and PK/PD correlation in burn children $(\mathrm{n}=6)$

\begin{tabular}{|c|c|c|c|c|c|c|c|}
\hline \multirow{2}{*}{$\frac{\text { Parameters }}{\text { Patient allocation }}$} & \multicolumn{3}{|c|}{ Pharmacokinetics (10 sets) } & \multicolumn{4}{|c|}{$\begin{array}{l}\text { PK/PD Correlation (10 sets) } \\
{ }^{13} \text { MIC values }\end{array}$} \\
\hline & $\begin{array}{l}\mathrm{t}_{(1 / 2) \beta} \\
(\mathrm{h})\end{array}$ & $\begin{array}{c}\mathrm{CL}_{\mathrm{T}} \\
\text { (mL/min.kg) }\end{array}$ & $\begin{array}{l}\mathrm{Vd}^{\mathrm{ss}} \\
(\mathrm{L} / \mathrm{kg})\end{array}$ & $0.5 \mathrm{mg} / \mathrm{L}$ & $1 \mathrm{mg} / \mathrm{L}$ & $2 \mathrm{mg} / \mathrm{L}$ & $4 \mathrm{mg} / \mathrm{L}$ \\
\hline$\# 1(\operatorname{set} 1)$ & 1.3 & 1.4 & 0.16 & 100 & 100 & 100 & 99 \\
\hline$\# 1(\operatorname{set} 2)$ & 0.5 & 2.4 & 0.10 & 70 & 61 & 53 & 36 \\
\hline$\# 2$ & 1.7 & 0.9 & 0.14 & 100 & 100 & 100 & 100 \\
\hline$\# 3$ & 0.8 & 3.8 & 0.26 & 100 & 104 & 90 & 63 \\
\hline$\# 4(\operatorname{set} 1)$ & 2.4 & 1.4 & 0.30 & 100 & 100 & 100 & 100 \\
\hline$\# 4(\operatorname{set} 2)$ & 1.6 & 13.1 & 1.78 & 100 & 94 & 74 & 34 \\
\hline$\# 5(\operatorname{set} 1)$ & 1.9 & 1.9 & 0.32 & 100 & 100 & 100 & 100 \\
\hline$\# 5(\operatorname{set} 2)$ & 4.8 & 6.4 & 2.68 & 100 & 100 & 100 & 100 \\
\hline \#5 $(\operatorname{set} 3)$ & 1.0 & 2.2 & 0.19 & 100 & 100 & 100 & 79 \\
\hline$\# 6$ & 0.4 & 5.5 & 0.17 & 91 & 85 & 78 & 65 \\
\hline Median & 1.45 & 2.3 & 0.23 & 100 & 100 & 100 & 89 \\
\hline IQ (25/75\%) & $0.85-1.85$ & $1.5-5.1$ & $0.16-0.32$ & $100-100$ & $96-100$ & $81-100$ & $64-100$ \\
\hline$\% \mathrm{TA}(40 \% f \mathrm{~T}>\mathrm{MIC})$ & NAP & NAP & NAP & $100 \%$ & $100 \%$ & $100 \%$ & $80 \%$ \\
\hline
\end{tabular}

Abbreviations and symbols - $\mathrm{t}_{(1 / 2) \mathrm{\beta}}$ : biological half-life; $\mathrm{CL}_{\mathrm{T}}$ : total body clearance; $\mathrm{Vd}^{\text {ss: }}$ : apparent volume of distribution; TA: Target attainment; MIC: minimum inhibitory concentration; $f \mathrm{~T}>\mathrm{MIC}$ : percentage of the dosing interval that free drug plasma concentration remains above the MIC; NAP: not applied; IQ: Quartile (25-75\%).

\section{Therapeutic drug monitoring}

Imipenem plasma monitoring was performed in six pediatric burn patients, covering 10 sets of plasma levels. The investigated pharmacokinetics of a dosage of $2 \mathrm{~g}$ daily each 6 hours are described in Table III. Additionally, drug efficacy was evaluated by the previously reported PK/ PD correlation (Zhanel et al., 2007; Ikawa et al., 2008). Free-fraction drug plasma concentrations were maintained above the MIC within the time interval ( $f \mathrm{~T}>\mathrm{MIC})$, expressed as a percentage, and imipenem effectiveness is guaranteed at $40 \% f \mathrm{~T}>\mathrm{MIC}$. PK/PD modelling was investigated; the estimated data for the predictive index are described in Table III.

In critically ill adult burn patients, extensive changes in drug kinetic disposition were reported for many drugs, including imipenem (Weinbren, 1999; Belzeberg et al., 2004; Blanchet et al., 2008). The pharmacokinetics of imipenem in adults have been described by Dailly et al. (2003); the changes in burn patients were related to an increased distribution volume, with a consequent prolongation of the biological half-life (Drusano et al., 1984). In addition, a prolongation of biological half-life is expected if a decrease in drug plasma clearance and an increase in the distribution volume of critically ill patients occurs (Belzeberg et al., 2004).
The pharmacokinetic data for imipenem obtained in pediatric burn patients investigated in the present study varied greatly from data previously reported for septic adult burn patients and critically ill adult patients (Dailly et al., 2003; Belzeberg et al., 2004). Because kinetic disposition is quite different between adult patients and pediatric patients due to differences in body size, fluid compartments and drug elimination by urinary excretion or drug metabolism (Onishi et al., 2005), these data may agree with the previous studies.

$\mathrm{PK} / \mathrm{PD}$ data obtained in the present study were based on in vitro microbial susceptibility testing (MIC data) of pathogens isolated from blood, fluids or secretions collected from pediatric burn inpatients and measured as part of routine clinical practice in the hospital Central Laboratory. In addition, if the MIC hospital data were not available on time, the PK/PD results were estimated based on available data (EUCAST, 2013).

Then, according to Figure 2, drug effectiveness was obtained in $100 \%$ of the plasma sets based on MIC hospital data obtained up to $2 \mathrm{mg} / \mathrm{L}$, considering hospital Gram-positive or Gram-negative pathogens isolated from fluids or secretions of each patient. In contrast, imipenem effectiveness was reduced by $20 \%$ for Gram-positive pathogens (Enterococcus faecium, Enterococcus faecalis; MIC: $4 \mathrm{mg} / \mathrm{L}$ ), with unchanged drug effectiveness against 
Gram-negative pathogens (MIC 0.25 - $2 \mathrm{mg} / \mathrm{L}$ ) relative to the Eucast database.

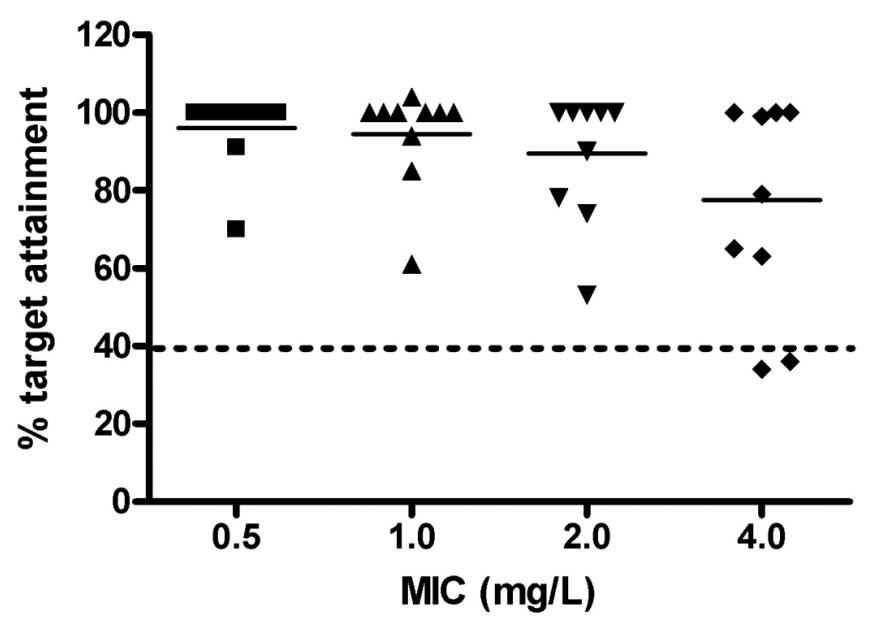

FIGURE 2 - Imipenem target achievement (40\% $f \mathrm{~T}>\mathrm{MIC}$; Ikawa et al., 2008) in 10 sets investigated for six paediatric burn patients.

Imipenem ( $2 \mathrm{~g}$ daily, 0.5 hour infusion of $0.5 \mathrm{~g}$ every 6 to 8 hours) provides sufficient drug exposure in the pediatric burn patients investigated in the present study according to data reported previously in critically ill adult patients (Dailly et al., 2003; Xu et al., 2009).

$\mathrm{PK} / \mathrm{PD}$ data obtained for pediatric burn patients were estimated based on the percentage of the dose interval that the drug plasma concentration was maintained above the MIC, and the time-dependent imipenem effectiveness criterion was considered to be $40 \%$ $f \mathrm{~T}>\mathrm{MIC}$, as recommended by Ikawa et al. (2008). Drug effectiveness against isolated pathogens during the antimicrobial susceptibility testing reached MIC values of $2 \mathrm{mg} / \mathrm{L}$ for patients in all sets investigated.

\section{CONCLUSION}

The bioanalytical method validated for imipenem plasma measurements by LC presented several advantages, such as simplicity, rapidity, specificity and selectivity and low required plasma volume, with acceptable confidence limits related to linearity, sensitivity and stability for the drug plasma assay. The method was appropriate for drug plasma measurements focused on drug efficacy to treat sepsis described in severe pediatric burn patients. A high PK/PD target for imipenem was attained in burned children. Finally, despite the altered pharmacokinetics for imipenem in pediatric burn patients, drug effectiveness was guaranteed in all sets investigated for isolated strains
(MIC $2 \mathrm{mg} / \mathrm{L}$ ) receiving the recommended daily dose $(2 \mathrm{~g})$ at a dose regimen of $0.5 \mathrm{~g} 4$ times a day.

\section{ACKNOWLEDGEMENTS}

This work was supported by FAPESP.

Authors are grateful to Mrs. Adriana Maria dos Santos for the technical laboratory support in drug plasma measurements.

\section{REFERENCES}

BELZEBERG, H.; ZHU, J.; CORNWELL III, E.E.; MURRAY, J.A.; SAVA, J.; SALIM, A.; VELMAHOS, G.C.; GILL, M.A. Imipenem levels are not predictable in the critically ill patient. J. Trauma, v.56, n.1, p.111-117, 2004.

BLANCHET, B.; JULLIEN, V.; VINSONNEAU, C.; TOD, M. Influence of burns on pharmacokinetics and pharmacodynamics of drugs used in the care of burn patients. Clin. Pharmacokinet., v.47, n.10, p.635-654, 2008.

BUCKLEY, M.M.; BROGDEN, R.N.; BARRADELL, L.B.; GOA, K.L. Imipenem cilastatin. A reappraisal of its antibacterial activity, pharmacokinetic properties and therapeutic efficacy. Drugs, v.44, n.3, p.408-444, 1992.

CLINICALAND LABORATORY STANDARDS INSTITUTE. CLSI. Performance Standards for antimicrobial susceptibility testing; Seventeenth Informational Supplement. CLSI document M100-S17, Pennsylvania, USA, 2007.

DAILLY, E.; BOUQUIÉ, R.; DESLANDES, G.; JOLLIET, P.; LE FLOCH, R. A liquid chromatography assay for a quantification of doripenem, ertapenem, imipenem, meropenem concentrations in human plasma: application to a clinical pharmacokinetic study. J. Chromatogr. B., v.879, n.15-16, p.1137-1142, 2011.

DAILLY, E.; KERGUERIS, M.F.; PANNIER, M.; JOLLIET, P.; BOURIN, M. Population pharmacokinetics of imipenem in burn patients. Fundam. Clin. Pharmacol., v.17, n.6, p.645-650, 2003.

DRUSANO, G.L.; STANDIFORD, H.C.; BUSTAMANTE, C.; FORREST, A.; RIVERA, G.; LESLIE, J.; TATEM, B.; DELAPORTAS, D.; MACGREGOR, R.R.; SCHIMPFF, S.C. Multiple-dose pharmacokinetics of imipenemcilastatin. Antimicrob. Agents Chemother, v.26, n.5, p.715$721,1984$. 
EBEY, W.J.; BOUCHER B. A.; PIEPER, J.A. A rapid HPLC method for determination of imipenem in plasma. J. Liq. Chromatogr., v.11, n.16, p.3471-3481. 1988.

\section{EUROPEAN COMMITTEE OF ANTIMICROBIAL} SUSCEPTIBILITY TESTING. EUCAST -. MICdistribution. Available at: <http://www.eucast.org/mic distributions $>$. Accessed on: 15 Sept 2013.

FOOD AND DRUG ADMINISTRATION. FDA Guidance for Industry: Bioanalytical Method Validation. US Department of Health and Human Services, Food and Drug Administration, Center for Drug Evaluation and Research, 2001.

FRY, D.E. The importance of antibiotic pharmacokinetics in critical illness. Am. J. Surg., v.172, n.6, p.20S-25S, 1996.

GARCIA-CAPDEVILA, L.; LÓPEZ-CALULL, C.; ARROYO, C.; MORAL, M.A.; MANGUES, M.A.; BONAL, J. Determination of imipenem in plasma by high-performance liquid chromatography for pharmacokinetic studies in patients. J. Chromatogr. B Biomed. Sci. Appl., v.692, n.1, p.127-32, 1997.

GRAVALLESE, D.A.; MUSSON, D.G.; PAULIUKONIS, L.T.; BAYNE, W.F. Determination of imipenem (N-formimidoyl thienamycin) in human plasma and urine by highperformance liquid chromatography, comparison with microbiological methodology and stability. J. Chromatogr., v.310, n.1, p.71-84, 1984

GREENHALGH, D.G.; SAFFLE, J.R.; HOLMES, J.H.; GAMELLI, R.L.; PALMIERI, T.L.; HORTON, J.W.; TOMPKINS, R.G.; TRABER, D.L.; MOZINGO, D.W.; DEITCH, E.A.; GOODWIN, C.W.; HERNDON, D.N.; GALLAGHER, J.J.; SANFORD, A.P.; JENG, J.C.; AHRENHOLZ, D.H.; NEELY, A.N.; O'MARA, M.S.; WOLF, S.E.; PURDUE, G.F.; GARNER, W.L.; YOWLER, C.J.; LATENSER, B.A.; AMERICAN BURN ASSOCIATION CONSENSUS CONFERENCE ON BURN SEPSIS AND INFECTION GROUP. American Burn Association consensus conference to define sepsis and infection in burns. J. Burn Care Res., v.28, n.6, p.77690, 2007.

IKAWA, K.; MORIKAWA, N.; IKEDA, K.; OHGE, H.; SUEDA, T. Development of breakpoints of carbapenems for intraabdominal infections based on pharmacokinetics and pharmacodynamics in peritoneal fluid. J. Infect. Chemother., v.14, n.4, p.330-332, 2008.
KURIHARA, Y.; KIZU, J.; HORI, S. Simple and rapid determination of serum carbapenem concentrations by highperformance liquid chromatography. J. Infect. Chemother., v.14, n.1, p.30-34, 2008.

LEGRAND, T.; CHUN, S.; REY, E.; BLANCHET, B.; ZAHAR, J.R.; LANTERNIER F.; PONS, G.; JULLIEN, v.Simultaneous determination of three carbapenem antibiotics in plasma by HPLC with ultraviolet detection. J. Chromatogr. B., v.875, n.2, p.551-556, 2008.

ONISHI, A.; YANO, Y.; ISHIBASHI, T.; KATSUBE, T.; OGUMA, T. Evaluation of bayesian predictability of vancomycin concentration using population pharmacokinetic parameters in paediatric patients. Drug Metab. Pharmacokinet., v.20, n.6, p.415-422, 2005.

PIETROSKI, N.A.; GRAZIANI, A.L.; LAWSON, L.A.; BLAND, J.A.; ROGERS, J.D.; MACGREGOR, R.R. Steady-State Pharmacokinetics of Intramuscular ImipenemCilastatin in Elderly Patients with Various Degrees of Renal Function. Antimicrob. Agents Chemother., v.35, n.5, p.972-975, 1991.

SCHWARTZ, G.J.; HAYCACK, G.B.; EDELMANN, C.M.; SPITZER, A. A simple estimate of glomerular filtration rate in children derived from body length and plasma creatinine. Paediatrics, v.58, p.259-263, 1976.

TANIGUCHI, S.; HAMASE, K.; KINOSHITA, A.; ZAITSU, K. Simple and rapid analytical method for carbapenems using capillary zone electrophoresis. J. Chromatogr. B., v.727, n.1-2, p.219-225, 1999.

VERDIER, M.C.; TRIBUT, O.; TATTEVIN, P.; LE TULZO, Y.; MICHELET, C.; BENTUÉ-FERRER, D. Simultaneous determination of 12 beta-lactam antibiotics in human plasma by high-performance liquid chromatography with UV detection: application to therapeutic drug monitoring. Antimicrob. Agents Chemother., v.55, n.10, p.4873-4879, 2011.

WEINBREN, M.J. Pharmacokinetics of antibiotics in burn patients. J. Antimicrob. Chemother., v.44, n.3, p.319-327, 1999. 
XU, Y.; XIE, W.; MILLER-STEIN, C.M.; WOOLF, E.J. Hydrophilic interaction chromatography/tandem mass spectrometry for the simultaneous determination of three polar non-structurally related compounds, imipenem, cilastatin and an investigational beta-lactamase inhibitor, MK-4698, in biological matrices. Rapid Commun. Mass Spectrom., v.23, n.14, p.2195-2205, 2009.
ZHANEL, G.G.; WIEBE, R.; DILAY, L.; THOMSON, K.; RUBINSTEIN, E.; HOBAN, D.J.; NOREDDIN, A.M.; KARLOWSKY, J.A. Comparative review of the carbapenems. Drugs, v.67, n.7, p.1027-1052, 2007.

Received for publication on $31^{\text {st }}$ January 2014 Accepted for publication on $04^{\text {th }}$ November 2014 
